\title{
Receptors for Atrial Natriuretic Peptide Are Decreased in the Kidney of Rats with Streptozotocin-induced Diabetes Mellitus
}

\author{
Leonardo A. Sechi, ${ }^{\star \ddagger}$ Jean-Pierre Valentin, ${ }^{5}$ Chandi A. Griffin, ${ }^{\ddagger}$ Eva Lee, ${ }^{\S}$ Ettore Bartoli, ${ }^{\star}$ Michael H. Humphreys, ${ }^{\S}$ and \\ Morris Schambelan \\ ${ }^{*}$ Hypertension Unit, Department of Internal Medicine, University of Udine, Udine, Italy; and Divisions of ${ }^{\ddagger}$ Endocrinology and \\ ${ }^{8}$ Nephrology, San Francisco General Hospital, University of California, San Francisco, California 94110
}

\begin{abstract}
To determine whether decreased renal responsiveness to atrial natriuretic peptide (ANP) in diabetes is mediated by alterations in the renal ANP receptor, ANP receptor density and affinity were measured 17-20 d after streptozotocin injection and compared with values in vehicle-treated controls and streptozotocin-treated rats made euglycemic with insulin. Plasma ANP concentration was significantly greater in hyperglycemic diabetic rats than in control or euglycemic diabetic rats. Both in glomeruli and inner medulla, ANP receptor dissociation constant did not differ among the three study groups, whereas the maximum binding capacity was decreased significantly in hyperglycemic diabetics in comparison with controls and euglycemic diabetics. Glomerular clearance receptors were also decreased significantly in hyperglycemic diabetic rats in comparison with control and euglycemic diabetic rats. To determine whether the decreased number of renal ANP receptors in diabetic rats was associated with a decreased biological response, we measured ANP-dependent cyclic GMP (cGMP) accumulation by isolated glomeruli and inner medullary collecting duct cells in vitro. cGMP accumulation was significantly less in hyperglycemic diabetic rats than in controls or euglycemic diabetic rats both in the presence or absence of the phosphodiesterase inhibitor zaprinast. cGMP phosphodiesterase activity in inner medullary collecting duct cells obtained from control and hyperglycemic diabetic rats did not differ. Thus, the decreased number of biologically active ANP receptors in the kidneys of diabetic rats is accompanied by decreased biological responsiveness in vitro and provides a potential explanation for the reduction in renal sensitivity to ANP in this condition. (J. Clin. Invest. 1995. 95:2451-2457.) Key words: atrial natriuretic peptide • cyclic GMP • diabetes • kidney $\cdot$ receptors
\end{abstract}

\section{Introduction}

Increased exchangeable sodium $(1,2)$ and extracellular fluid volume (3) occur in diabetic humans and experimental animals,

Address correspondence to Leonardo A. Sechi, M.D., Hypertension Unit, Department of Internal Medicine, University of Udine, Ospedale Civile, Padiglione Medicine, 33100 Udine, Italy. Phone: 432-559804 or 552848; FAX: 432-42097.

Received for publication 1 March 1994 and in revised form 28 December 1994.

J. Clin. Invest.

(C) The American Society for Clinical Investigation, Inc.

0021-9738/95/06/2451/07 \$2.00

Volume 95, June 1995, 2451-2457 respectively. Whereas the kidney is the principal organ responsible for the chronic regulation of body sodium and fluid composition (4), renal disease per se is an unlikely explanation for these abnormalities since they can occur quite early in the disease, even when glomerular filtration rate is normal and proteinuria is minimal $(1,2)$. Enhanced renal tubular reabsorption and/ or impaired responses to natriuretic influences are more likely explanations.

In both rats (5-7) and humans (8) with insulinopenic diabetes, the glomerular and tubular response of the kidney to atrial natriuretic peptide (ANP) ${ }^{1}$ is decreased. The basis for this decreased responsiveness has not been established, but may involve an abnormality of renal ANP receptors. Three distinct natriuretic peptide receptors have been identified (9): ANPR-A and ANPR-B, also called GC-A and GC-B, are both membrane guanylyl cyclases that synthesize cyclic GMP (cGMP) as an intracellular second messenger $(9,10)$. ANPR-C, also known as the ANP clearance receptor, does not signal through activation of guanylyl cyclase, but may serve as a clearance receptor for natriuretic peptides; it may also function through intermediate guanine nucleotide regulatory proteins to inhibit adenylyl cyclase (11). While ANPR-A and ANPR-B have rather strict structural requirements for ligand binding (12-15), ANPR-C has less rigorous structural requirements and binds the internally deleted analogues of ANP (c-ANP) (12,16-18), compounds which do not activate the membrane guanylate cyclase.

ANPR-A and ANPR-C receptors and their mRNAs have been demonstrated in the kidney using in situ autoradiographic techniques $(19,20)$ and in situ hybridization $(21)$, respectively. This study was designed to investigate the type, number, and affinity of ANP receptors in the kidney of rats with streptozotocin (STZ)-induced diabetes and to assess the biological activity of these receptors by measuring ANP-dependent cGMP accumulation by glomeruli and inner medullary collecting duct cells (IMCD) isolated from these rats.

\section{Methods}

Preparation of diabetic rats. Male Sprague-Dawley rats (Bantin and Kingman, Inc., Fremont, CA), ranging in weight from 200 to $250 \mathrm{~g}$, were maintained on standard rat chow and tap water ad libitum with a 12-h light/dark cycle in a quiet environment. In 19 rats, diabetes mellitus was induced by intravenous administration of STZ (Sigma, Chemical Co., St. Louis, MO), $60 \mathrm{mg} / \mathrm{kg}$ body wt, dissolved in sodium citrate buffer $(0.1 \mathrm{~mol} /$ liter, $\mathrm{pH} 4.5)$ at a concentration of $20 \mathrm{mg} / \mathrm{ml}$ immediately before use. Control rats $(n=11)$, which were matched for age and weight at the time of STZ administration, received an equal volume of the vehicle. Animals were considered to be diabetic if blood glucose

\footnotetext{
1. Abbreviations used in this paper: ANP, atrial natriuretic peptide; $B_{\max }$, maximum binding capacity; IMCD, inner medullary collecting duct; PDE, phosphodiesterase; STZ, streptozotocin.
} 
levels were $350 \mathrm{mg} / \mathrm{dl}$ or greater $72 \mathrm{~h}$ after the injection. Diabetic rats were further divided into two subgroups: rats to which human recombinant insulin (Humulin $\mathrm{N}^{\bullet}$; Eli Lilly \& Co., Indianapolis, $\mathbf{I N}$ ) was administered once daily in a fixed dose $(2 \mathrm{U} / \mathrm{d}, n=11)$ to prevent ketosis, and rats to which insulin was administered in doses that were adjusted to achieve euglycemia (6-10 U/d, $n=8)$. Blood glucose levels were measured on a drop of blood obtained by tail vein nicking (Accucheck bG; Bio-Dynamics, Boehringer-Mannheim, Indianapolis, IN). To determine the 24-h urine volume and the rate of excretion of sodium and cGMP, rats were placed in metabolic cages on the day before killing. Rats were killed by decapitation 17-20 d after the administration of STZ, and trunk blood was collected for determination of plasma glucose and ANP levels. The kidneys were quickly removed, decapsulated, snapfrozen in liquid nitrogen, and stored at $-80^{\circ} \mathrm{C}$. Plasma ANP was measured by radioimmunoassay (Peninsula Laboratories, Inc., Belmont, CA), after extraction with $0.1 \%$ trifluoroacetic acid and $75 \%$ methanol.

Receptor binding studies. The density of ANP receptors was assessed by a modification of an in situ receptor binding assay (19) as reported previously (20). Briefly, tissue sections $(10 \mu \mathrm{m})$ were cut on a cryostat at $-15^{\circ} \mathrm{C}$, thaw-mounted on poly-L-lysine-coated slides, dried in vacuo for $18 \mathrm{~h}$ at -4 to $+4^{\circ} \mathrm{C}$ over silica gel, and stored in sealed Bakelite boxes at $-80^{\circ} \mathrm{C}$. Immediately before assay, the slides were brought to room temperature. Sections were preincubated for 10 min at room temperature in $100 \mu \mathrm{l}$ of a buffer (buffer A) containing $30 \mathrm{mM}$ sodium phosphate (pH 7.2), $120 \mathrm{mM}$ sodium chloride, $0.3 \%$ bacitracin, and $0.5 \%$ receptor grade bovine serum albumin. After preincubation, the buffer was replaced with $100 \mu \mathrm{l}$ of fresh buffer A containing increasing concentrations (from 25 to $1,500 \mathrm{pM}$ ) of $\left[{ }^{125} \mathrm{I}\right]$-ratANP (1-28) $(2,200 \mu \mathrm{Ci} / \mathrm{mmol}$; DuPont/New England Nuclear, Boston, MA), and the sections were placed in a humidified chamber and incubated at room temperature for $15 \mathrm{~min}$. After incubation, the slides were rinsed in an ice-cold buffer containing $30 \mathrm{mM}$ sodium phosphate and $120 \mathrm{mM}$ sodium chloride for $10 \mathrm{~s}$, washed in the same buffer for $5 \mathrm{~min}$, rinsed in deionized water for $10 \mathrm{~s}$, and dried for $2 \mathrm{~h}$ in a stream of cool air. For autoradiography, the sections were exposed to LKB-Ultrofilm (Leica Inc., Deerfield, IL) for 3-5 d at room temperature, and films were processed with Kodak D-19 developer and rapid fixer (Eastman Kodak Co., Rochester, NY). Thereafter, the amount of radioligand bound to the tissue sections was determined by placing the slides in a gamma counter. Regional analysis of ANP binding to glomeruli and inner medulla was performed using film autoradiography. Optical density in the different regions was measured by computerized microdensitometry (Image-Analysis-OS2; Imaging Research Inc., St. Catherines, Ontario, Canada).

Nonspecific binding was determined on adjacent sections under identical incubation conditions except for the addition of $1 \mu \mathrm{M}$ unlabeled rat ANP (1-28) (Peninsula Laboratories, Inc.). ANPR-C receptors were identified by addition of $10 \mu \mathrm{M}$ c-ANP (4-23) (Peninsula Laboratories, Inc.). ANPR-A receptors were calculated by subtraction of ANPR-C receptors from total ANP receptors. The apparent dissociation constant $\left(K_{d}\right)$ and the maximal binding capacity $\left(B_{\max }\right)$ were calculated by Scatchard analysis using the LIGAND program of Munson and Rodbard (22). Because $10 \mu \mathrm{M}$ c-ANP (4-23) could theoretically occupy some of the ANPR-A receptors, we performed experiments in which IMCD cells obtained from kidneys of normal rats were incubated with $10 \mu \mathrm{M} \mathrm{c}$ ANP (4-23) and cGMP production was measured (see below). Accumulation of cGMP did not differ significantly in cells incubated with or without cGMP $(126 \pm 15 \mathrm{vs} 119 \pm 21 \mathrm{fmol} / \mathrm{mg}$ protein per $10 \mathrm{~min}$, respectively), ruling out the possibility of significant c-ANP binding to ANPRA receptors at this concentration.

Preparation of isolated glomeruli and IMCD cells. Under Inactin ${ }^{\star}$ (BYK, Gulden, Germany) anesthesia (100 mg/kg body wt, intraperitoneally), the suprarenal aorta was cross-clamped via the distal aorta, and the kidneys were flushed with cold isotonic saline (5-10 ml). Glomeruli were isolated as described previously (23). In brief, for each preparation the renal cortices were dissected and minced to a pastelike consistency. The homogenate was passed successively through a 106- $\mu \mathrm{m}$ sieve that excluded the tubules and blood vessels and a 75- $\mu \mathrm{m}$ sieve that retained the glomeruli and allowed cells and small debris to pass through. Glo- meruli were suspended in ice-cold $20 \mathrm{mM}$ Tris- $\mathrm{HCl}$ buffer, $\mathrm{pH} \mathrm{7.4,}$ containing $135 \mathrm{mM}$ sodium chloride, $10 \mathrm{mM}$ potassium chloride, 10 $\mathrm{mM}$ sodium acetate, and $5 \mathrm{mM}$ glucose (buffer B) and centrifuged at $120 \mathrm{~g}$ for $2 \mathrm{~min}$. The supernatant was discarded, and the pellet was resuspended in the same buffer and recentrifuged. By light microscopic examination, the final pellet consisted of nearly pure isolated decapsulated glomeruli with $<5 \%$ contamination with tubules. No afferent or efferent arterioles were observed.

IMCD cells were isolated as follows (24): the kidneys were perfused with $50-60 \mathrm{ml}$ of saline followed by $5 \mathrm{ml}$ of saline containing $0.2 \%$ of collagenase (type II; Sigma Chemical Co.). The inner medullae were excised, finely minced, and incubated in the same solution for $90 \mathrm{~min}$ at $37^{\circ} \mathrm{C}$. The resulting suspension of inner medullary cells was layered on a $16 \%$ Ficoll (Sigma Chemical Co.) solution in nonbicarbonate Ring-

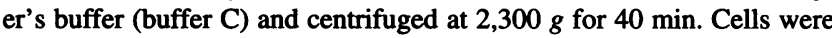
subsequently washed through buffer $\mathrm{C}$ and then a solution of buffer $\mathrm{C}$ containing $7.5 \%$ albumin to remove traces of contaminating collagenase.

Determination of cGMP accumulation by glomeruli and IMCD cells. Freshly isolated glomeruli were resuspended in buffer B with $1 \mathrm{mM}$ calcium chloride and IMCD cells in buffer $C$ containing $7.5 \mathrm{mM}$ glucose. $350-\mu \mathrm{l}$ aliquots containing $0.2-0.5 \mathrm{mg}$ protein/tube were preincubated for $10 \mathrm{~min}$ at $37^{\circ} \mathrm{C}$ in a shaking water bath. Incubations were then carried out for $10 \mathrm{~min}$ at $37^{\circ} \mathrm{C}$ with varying doses of ANP $\left(10^{-10}\right.$ to $10^{-6} \mathrm{M}$ ), in the presence or absence of a phosphodiesterase (PDE) inhibitor, zaprinast (1 mM, M\&B 22,948; Rhone-Poulenc, Rorer, Dagenham, United Kingdom). Incubations were terminated by adding 750 $\mu \mathrm{l}$ of ice-cold trichloroacetic acid (TCA; final concentration, $6.6 \%$ ) and cooling to $4^{\circ} \mathrm{C}$. The precipitated protein was sedimented by centrifugation at $4,500 \mathrm{rpm}$ for $15 \mathrm{~min}$ at $4^{\circ} \mathrm{C}$, and the pellets were dissolved in $0.5 \mathrm{~N}$ sodium hydroxide and assayed for protein content by the method of Lowry (25) using bovine serum albumin as a standard. The supernatant fluid was extracted five times with four volumes of water-saturated ethyl ether to remove the TCA before being evaporated to dryness under a stream of air and stored at $-70^{\circ} \mathrm{C}$ until assayed for cGMP content. For the cGMP assay, samples were dissolved in $50 \mathrm{mM}$ sodium acetate buffer, pH 6.2, mixed thoroughly, and $100 \mu \mathrm{l}$ aliquots acetylated and assayed in duplicate with a commercially available kit according to the manufacturer's instructions (New England Nuclear). Results are expressed as femtomoles of cGMP generated per milligram of protein per $10 \mathrm{~min}$ of incubation.

Preparation of IMCD cell membranes and cytosol. IMCD cell membranes were prepared by homogenizing freshly dispersed cells in 10 mM Tris- $\mathrm{HCl}$ (pH 7.4), $10 \mathrm{mM}$ Mes, 1 mM EDTA, 1 mM EGTA, 0.1 $\mu \mathrm{M}$ leupeptin, $0.1 \mu \mathrm{M}$ pepstatin, $0.1 \mu \mathrm{M}$ PSMF, $0.25 \mathrm{M}$ sucrose, $5 \mathrm{mM}$ 2-mercaptoethanol, and $0.1 \%$ Triton X-100. Cytosol was obtained by homogenizing cells in a buffer containing $5 \mathrm{mM}$ Tris- $\mathrm{HCl}$ (pH 7.4), 3 $\mathrm{mM} \mathrm{MgCl}$, and $1 \mathrm{mM}$ EDTA, in an amount equal to $1: 3$ wet wt/ volume. In each case, cells were homogenized in a Potter-type Teflonglass homogenizer for $10-12$ strokes at $4^{\circ} \mathrm{C}$; the homogenates were initially centrifuged at $200 \mathrm{~g}$ for $5 \mathrm{~min}$ and the resultant supernatants were incubated with agitation at $4^{\circ} \mathrm{C}$ for $60 \mathrm{~min}$ followed by centrifugation at $100,000 \mathrm{~g}$ for $60 \mathrm{~min}$. The resulting pellets containing membranes were resuspended in 1:10 vol/vol homogenizing buffer, rehomogenized, and again ultracentrifuged, while the supernatants representing the cytosolic fraction were stored on ice. The supernatant from the second high speed centrifugation was added to that previously collected and immediately frozen at $-70^{\circ} \mathrm{C}$ for subsequent determination of PDE activity, and the pellet resuspended in $100 \mathrm{mM}$ Hepes (pH 7.4) and 50 $\mathrm{mM} \mathrm{NaCl}$ for assay of guanylate cyclase activity.

Determination of guanylate cyclase activity in IMCD cells membranes. Guanylate cyclase activity was assayed by a modification of the method of Cunning (26). Briefly, enzyme activity was determined by incubation of $40-100 \mu \mathrm{g}$ of membrane protein with 4-5 mM GTP substrate in the presence of $2 \mathrm{mM}$ manganese, $1.2 \mathrm{mM}$ isoutylmethylxanthine, $5 \mathrm{mM}$ theophylline, creatine phosphokinase $(3 \mathrm{U})$, and 7.5 $\mathrm{mM}$ phosphocreatine. All incubations were performed for $5 \mathrm{~min}$ at $37^{\circ} \mathrm{C}$ and terminated by $12 \%$ TCA precipitation. After centrifugation, the supernatants were ether extracted, air-dried, and reconstituted in $50 \mathrm{mM}$ sodium acetate ( $\mathrm{pH}$ 6.2) followed by cGMP measurements in duplicate 

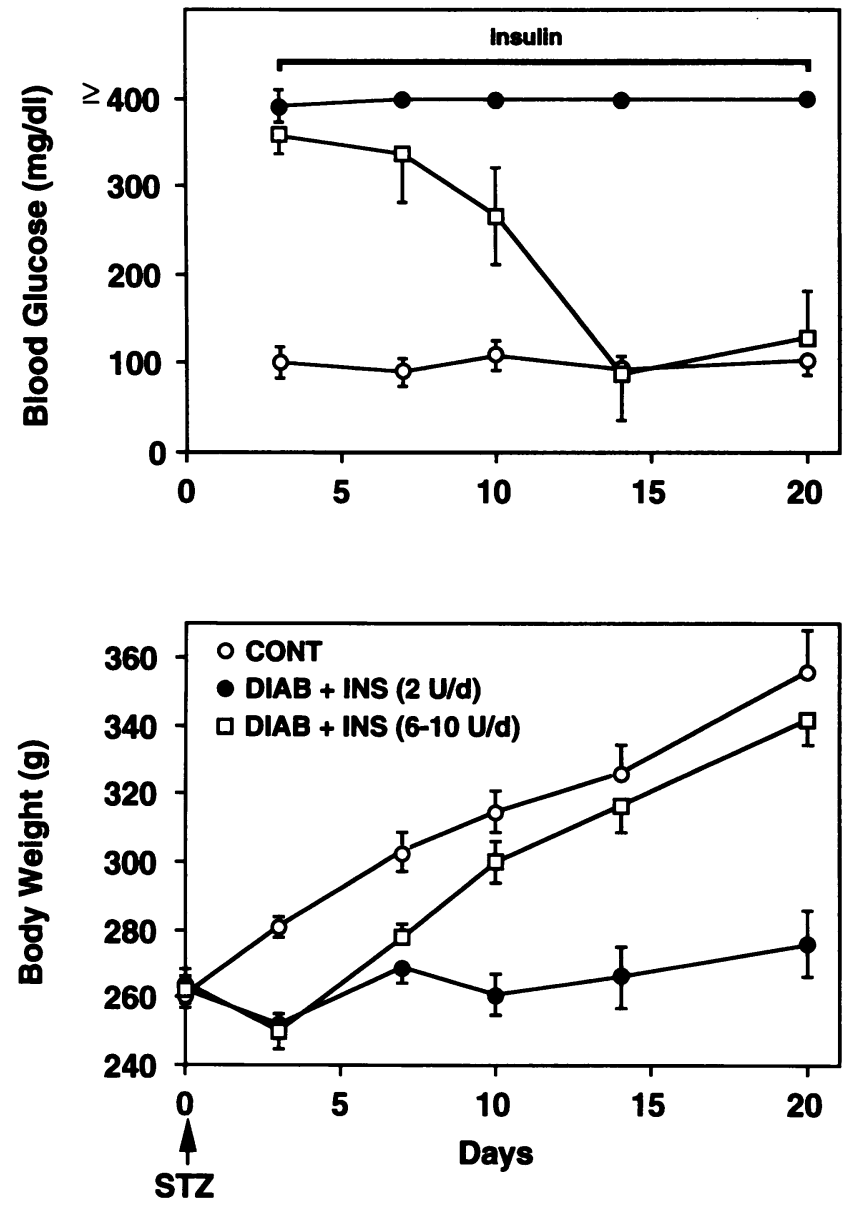

Figure 1. Blood glucose concentration (top) and body weight (bottom) in control, low-dose, and high-dose insulin-treated diabetic rats. Hyperglycemia occurred within $3 \mathrm{~d}$ of administration of STZ and persisted thereafter in the rats that received low-dose insulin therapy. Hyperglycemia was completely ameliorated in the rats that received the higher doses of insulin. Rats treated with the higher doses of insulin gained weight rapidly, reaching values not significantly different from control at the end of the experimental period, whereas the rate of growth was significantly slower in rats treated with low-dose insulin. Data are mean \pm SEM of 11 control, 11 low-dose, and 8 high-dose insulin-treated animals.

by radioimmunoassay. cGMP production was linear as a function of incubation time (1-10 min) and protein concentration $(10-100 \mu \mathrm{g})$. Protein concentration was determined by the Coomassie protein assay.

Determination of PDE activity in IMCD cells. cGMP PDE activity was assayed according to the method of Torres et al. (27). Cytosolic fractions of IMCD cell homogenates, collected as described (10-15 $\mu \mathrm{g}$ protein/tube), were incubated with $1 \mu \mathrm{M}\left[{ }^{3} \mathrm{H}\right] \mathrm{cGMP}$ (New England Nuclear) in $200 \mu \mathrm{l}$ of a buffer containing $10 \mu \mathrm{M}$ magnesium sulphate, $2 \mathrm{mM}$ EGTA, $0.1 \%$ bovine serum albumin, and $50 \mathrm{mM}$ Tris- $\mathrm{HCl}(\mathrm{pH}$ 7.5). After a 20 -min incubation period at $37^{\circ} \mathrm{C}$, the reaction was stopped by heating at $95^{\circ} \mathrm{C}$ for $3 \mathrm{~min}$, and the ${ }^{3} \mathrm{H}-5^{\prime}$-nucleotide products converted to ${ }^{3} \mathrm{H}$-nucleosides by incubation with an excess of $5^{\prime}$-nucleotidase (Crotalus atrox snake venom; Sigma Chemical Co.). Nucleosides were separated from nucleotides on a QAE-Sephadex column according to the procedure of Wells et al. (28) and column eluates counted for ${ }^{3} \mathrm{H}$ activity in a liquid scintillation counter. Enzyme activity is expressed in picomoles of cGMP hydrolyzed per minute per milligram of protein. With this assay, activity was linear over time and with protein concentration.

Statistical analysis. Data are presented as mean \pm standard error.
Table I. Characteristics of Control, Hyperglycemic Diabetic, and Euglycemic Diabetic Rats

\begin{tabular}{|c|c|c|c|}
\hline & \multirow[b]{2}{*}{ Control } & \multicolumn{2}{|c|}{ Diabetic } \\
\hline & & Hyperglycemic & Euglycemic \\
\hline$n$ & 11 & 7 & 8 \\
\hline Body wt $(g)$ & $356 \pm 12$ & $285 \pm 9 *$ & $342 \pm 8$ \\
\hline Kidney wt $(g)$ & $2.37 \pm 0.07$ & $2.46 \pm 0.07$ & $2.40 \pm 0.05$ \\
\hline \multicolumn{4}{|l|}{ Kidney/body wt ratio } \\
\hline$(\times 100)$ & $0.67 \pm 0.01$ & $0.86 \pm 0.02 *$ & $0.70 \pm 0.02$ \\
\hline Blood glucose $(m g / d l)$ & $128 \pm 5$ & $486 \pm 41 *$ & $105 \pm 30$ \\
\hline Plasma ANP $(p g / m l)$ & $229 \pm 20$ & $312 \pm 33^{\ddagger}$ & $178 \pm 22$ \\
\hline Urinary vol $(m / 24 h)$ & $19.7 \pm 1.6$ & $117.0 \pm 7.0^{*}$ & $30.8 \pm 4.8$ \\
\hline \multicolumn{4}{|l|}{ Sodium excretion } \\
\hline$(m M / 24 h)$ & $1.96 \pm 0.23$ & $2.50 \pm 0.29$ & $2.14 \pm 0.03$ \\
\hline \multicolumn{4}{|l|}{ cGMP excretion } \\
\hline$(n M / 24 h)$ & $41.6 \pm 5.2$ & $37.8 \pm 6.4$ & $32.5 \pm 3.7$ \\
\hline
\end{tabular}

Values are means \pm SEM. Significant difference versus control rats is indicated by $* P<0.01$, and ${ }^{\ddagger} P<0.05$.

Comparisons were done by ANOVA (Statview; BrainPower Inc., Calabasas, CA). A $P$ value $<5 \%$ was considered to be statistically significant.

\section{Results}

Blood glucose, body weight, and plasma ANP. Hyperglycemia occurred within $3 \mathrm{~d}$ of administration of STZ and persisted thereafter in the rats that received low-dose insulin therapy (Fig. 1, Table I). Hyperglycemia was completely ameliorated in the rats that received the higher doses of insulin (Fig. 1, Table I). Rats treated with the higher doses of insulin gained weight rapidly, reaching values not significantly different from control at the end of the experimental period (Fig. 1, Table I), whereas the rate of growth was significantly slower in the rats with persistent hyperglycemia. The kidney weight at the end of the experiment was comparable in the three groups, although the kidney weight/body weight ratio was significantly greater ( $P$ $<0.01)$ in the hyperglycemic diabetic than in control and euglycemic diabetic rats (Table I).

Plasma levels of ANP were significantly greater in hyperglycemic diabetic rats than in control rats (Table I). The administration of insulin to diabetic rats in doses sufficient to maintain their blood glucose concentration within the normal range resulted in a normalization of plasma levels of ANP.

ANP receptor binding. The distribution of $\left[{ }^{125} \mathrm{I}\right]-$ rat $\mathrm{ANP}$ binding in the kidney of control rats is shown in Fig. $2 A$. Binding of radioligand was found in both cortical and medullary regions of rat kidney. In the cortex, the radioligand binding was localized primarily in glomeruli. In the outer medulla, bound radioligand was found in longitudinal bands in the inner stripe, corresponding to medullary vascular bundles (29). Minimal radioligand binding was found in the interbundle areas, whereas binding to papillae was high. Nonspecific binding was $<10 \%$ (Fig. 2 B). Incubation with c-ANP markedly reduced binding of the radioligand to glomeruli (Fig. $2 \mathrm{C}$ ). A similar distribution of radioligand binding and pattern of inhibition by unlabeled ANP and c-ANP were found in the kidney of diabetic rats (Fig. $2 D)$. 


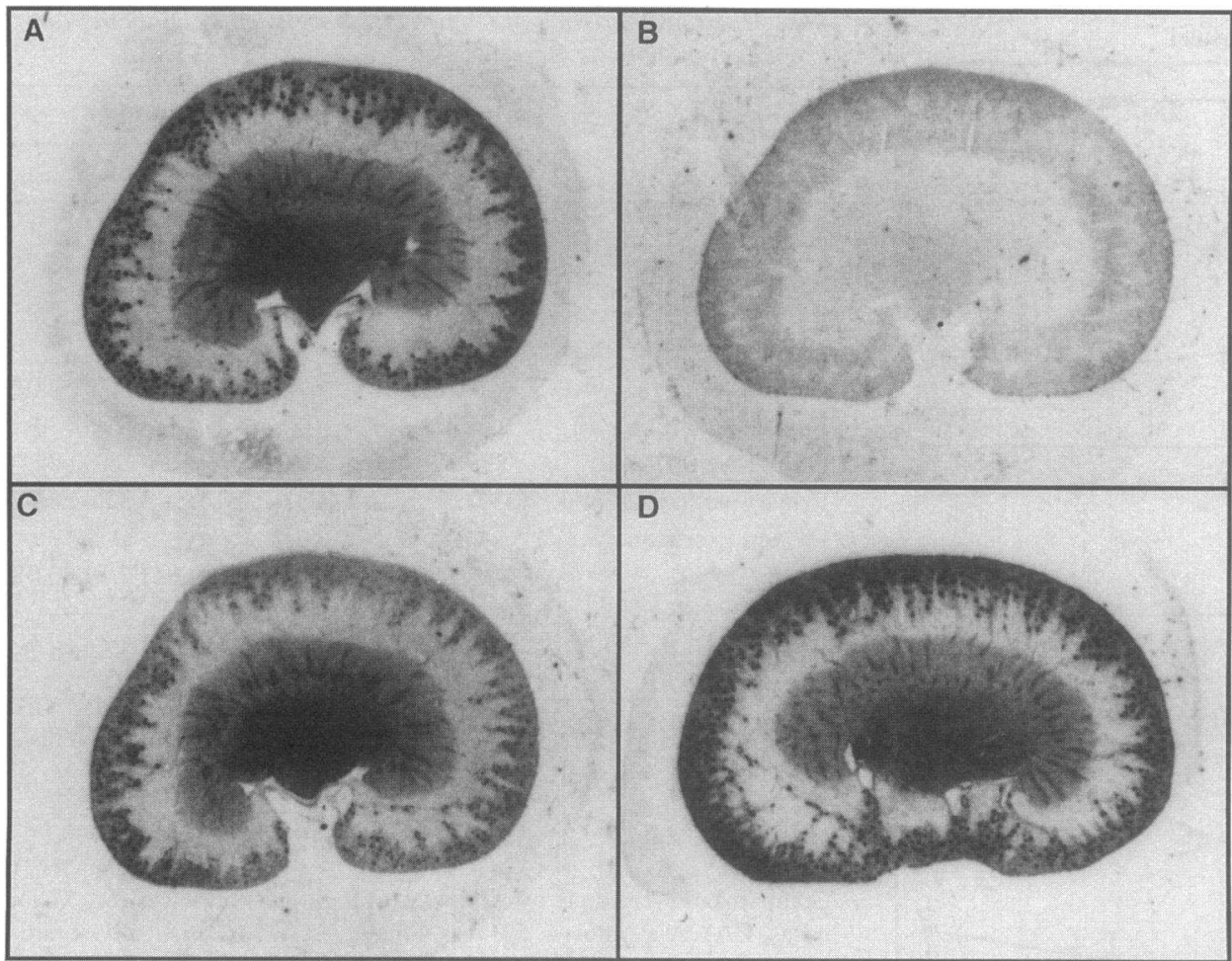

Figure 2. In situ autoradiographic localization of ANP receptors in rat kidney. Longitudinal sections of rat kidney were incubated with ${ }^{125}$ I-rANP. (A) Normal kidney. ANP binding was distributed primarily in glomeruli and in the inner medulla. $(B)$ Normal kidney. Incubation with $1 \mu \mathrm{mol} /$ liter unlabeled ANP (1-28) markedly inhibited radioligand binding. (C) Normal kidney. Incubation with $10 \mu \mathrm{mol} /$ liter unlabeled c-ANP (4-23) inhibited radioligand binding to glomeruli to a lesser degree. $(D)$ Diabetic kidney. ANP binding distribution was similar to control rats.
Increasing concentrations of radioligand resulted in an increase in both total and nonspecific binding. Receptor saturation was approached at $1.2 \mathrm{nmol} /$ liter in both control and hyperglycemic diabetic rats (Fig. 3). Scatchard analysis of these data sug-

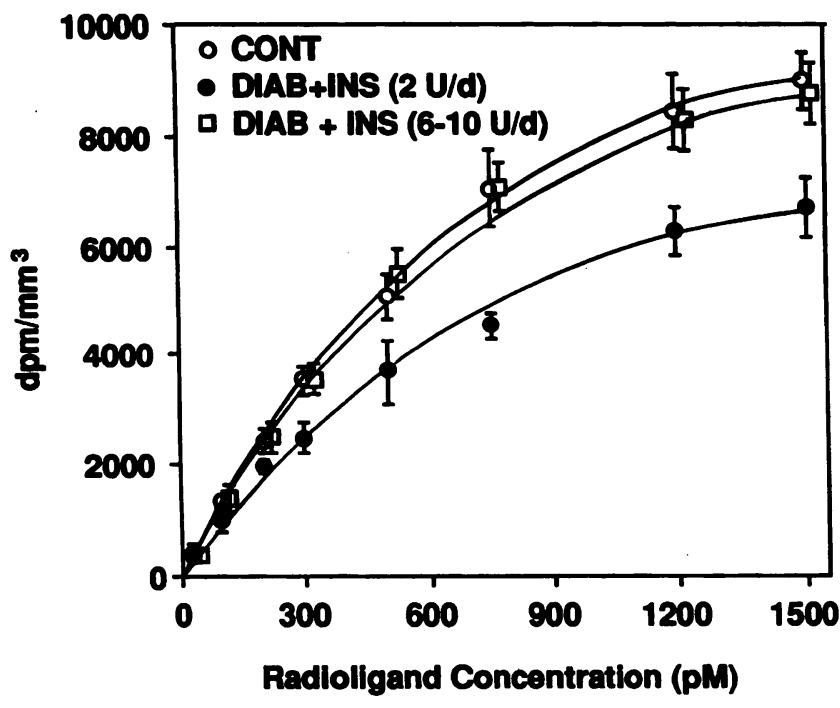

Figure 3. Saturation curves of radioligand binding in control, low-dose, and high-dose insulin-treated rats. Incubation of increasing concentrations of ${ }^{125}$ I-rANP with rat kidney sections resulted in an increase in both total and nonspecific binding. Receptor saturation, determined from the plot of specific binding, was approached at a concentration of $\mathbf{1 . 2}$ nmol/liter in both control and hyperglycemic diabetic rats. At all concentrations tested, specific binding was lower in hyperglycemic diabetic than in control rats. The ANP receptor saturation curve in high-dose insulin-treated diabetic rats was superimposed on that for control rats. Data are means \pm SEM of sections obtained from three rats in each group. Experiments were performed in duplicate. gested the presence of a single receptor site in each of the three experimental groups (Fig. 4). ANP receptor affinity, expressed as the apparent $K_{\mathrm{d}}$, did not differ among the three study groups, whereas the $B_{\max }$ for ANP was significantly decreased in hyperglycemic diabetic rats as compared with controls and normoglycemic diabetic rats. Regional analysis of ANP binding was performed by computerized microdensitometry and showed that ANPR-A receptor density was decreased both in glomeruli and inner medulla in the hyperglycemic diabetic rats. Equilibrium binding data obtained in glomeruli in the presence of c-ANP showed that the number of ANPR-C receptors was significantly lower in the kidney of hyperglycemic diabetic rats in comparison with controls and euglycemic diabetics (Table II).

cGMP accumulation by glomeruli and IMCD cells and guanylate cyclase activity. ANP induced a dose-dependent increase in glomerular cGMP generation in the three groups (Fig. 5). Both in glomeruli and IMCD cells, cGMP accumulation was lower in hyperglycemic diabetic rats than in controls at the higher concentrations used. Similar differences between hyperglycemic diabetic and control rats were found when glomeruli were incubated in the presence of zaprinast (Fig. 6), indicating that these differences could not be ascribed to an alteration in the activity of cGMP PDE. Guanylate cyclase activity was comparable in membranes obtained from IMCD cells in control $\left(5,983 \pm 548 \mathrm{fmol} \mathrm{GMP} \cdot \mathrm{mg}\right.$ protein $\left.{ }^{-1} \cdot \mathrm{min}^{-1}\right)$ and hyperglycemic diabetic $\left(5,835 \pm 814 \mathrm{fmol} \mathrm{GMP} \cdot \mathrm{mg}\right.$ protein $\left.{ }^{-1} \cdot \mathrm{min}^{-1}\right)$ rats, indicating no effect of diabetes on basal activity of this enzyme.

$P D E$ enzymatic activity in IMCD cells. Measurement of PDE enzymatic activity in IMCD cytosol showed comparable values in control $\left(180 \pm 28 \mathrm{fmol} \cdot \mathrm{mg}\right.$ protein $\left.{ }^{-1} \cdot \mathrm{min}^{-1}\right)$ and hyperglycemic diabetic rats $\left(156 \pm 23 \mathrm{fmol} \cdot \mathrm{mg}\right.$ protein $^{-1}$. $\min ^{-1}$; NS).

\section{Discussion}

This study demonstrates that the number of ANP receptors is decreased in the kidney of rats with STZ-induced diabetes melli- 


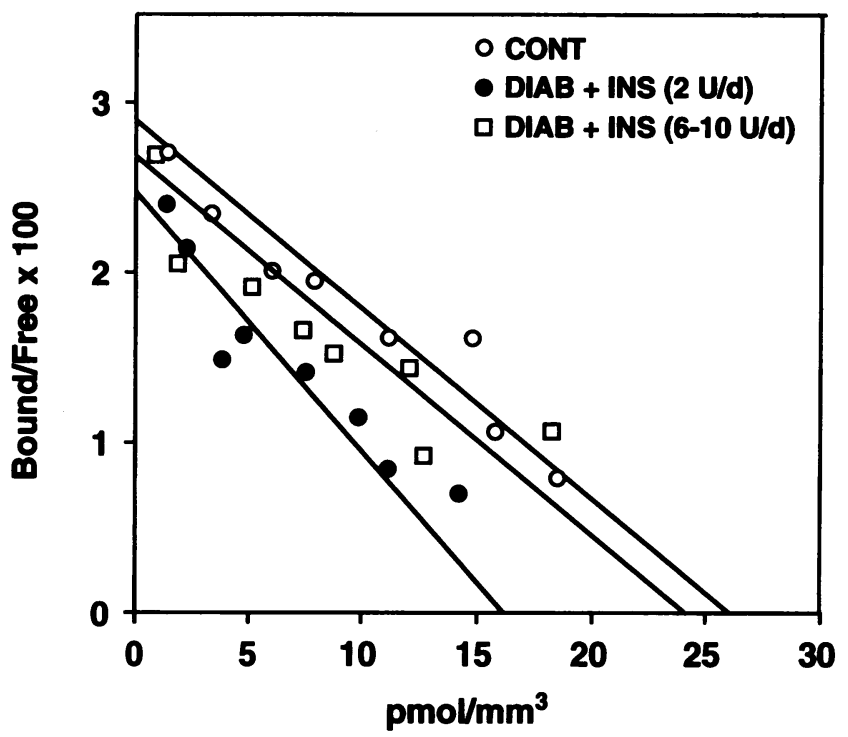

Figure 4. Representative Scatchard plots of ANP binding in control, low-dose, and high-dose insulin-treated rats. Plots obtained from analysis of saturation experiments are linear, suggesting the presence of a single receptor site. ANP receptor affinity $\left(K_{\mathrm{d}}\right)$ did not differ among the three study groups. The $B_{\max }$ for ANP was significantly decreased in hyperglycemic diabetic rats as compared with control and normoglycemic diabetic rats. Data are from one representative animal in each group. Experiments were performed in duplicate.

tus. This abnormality is associated with a decreased production of cGMP by glomeruli and IMCD cells which is not corrected by inhibition of PDE activity.

When studied 2 wk after administration of STZ, we found that plasma ANP levels in hyperglycemic diabetic rats were significantly increased in comparison with controls and that insulin therapy sufficient to achieve strict glycemic control normalized plasma ANP levels. In previous studies, plasma ANP levels in diabetic rats were increased as early as $1 \mathrm{wk}$ after STZ injection (30) and persisted at elevated levels for at least 6 wk $(7,31)$. Plasma ANP levels are also increased in patients with insulin-dependent diabetes mellitus and diabetic nephropathy

Table II. Binding Parameters of Biological (ANPR-A) and Clearance (ANPR-C) Receptors for ANP in the Kidney of Control, Hyperglycemic Diabetic, and Euglycemic Diabetic Rats

\begin{tabular}{lccr}
\hline & & \multicolumn{2}{c}{ Diabetic } \\
\cline { 3 - 4 } & Control & Hyperglycemic & Euglycemic \\
\hline$n$ & 3 & 3 & 3 \\
Glomeruli & & & \\
$\quad$ ANPR-A $K_{\mathrm{d}}(n M)$ & $1.2 \pm 0.4$ & $1.1 \pm 0.2$ & $1.4 \pm 0.5$ \\
ANPR-A $B_{\max }\left(p M / \mathrm{mm}^{3}\right)$ & $23.8 \pm 1.9$ & $14.1 \pm 3.1^{*}$ & $20.9 \pm 3.0$ \\
ANPR-C $K_{\mathrm{d}}(n M)$ & $0.5 \pm 0.3$ & $0.7 \pm 0.4$ & $0.6 \pm 0.2$ \\
ANPR-C $B_{\max }\left(p M / \mathrm{mm}^{3}\right)$ & $8.4 \pm 1.3$ & $4.7 \pm 1.2^{\ddagger}$ & $7.2 \pm 1.9$ \\
Inner medulla & & & \\
$\quad$ ANPR-A $K_{\mathrm{d}}(n M)$ & $1.3 \pm 0.3$ & $1.2 \pm 0.4$ & $1.8 \pm 0.7$ \\
ANPR-A $B_{\max }\left(p M / \mathrm{mm}^{3}\right)$ & $25.3 \pm 2.8$ & $13.7 \pm 2.7^{\ddagger}$ & $19.9 \pm 3.5$ \\
& & & \\
\hline
\end{tabular}

Values are means \pm SEM. Significant differences versus control rats are indicated by ${ }^{\ddagger} P<0.05$, and ${ }^{*} P<0.01$.
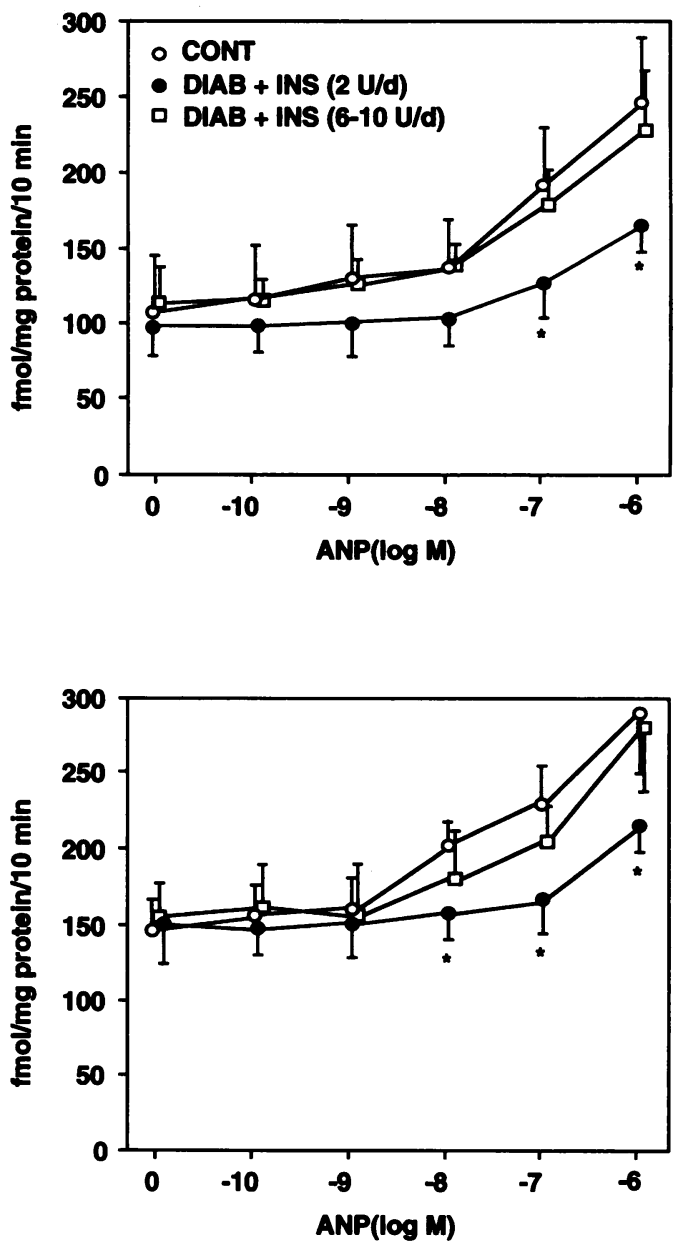

Figure 5. cGMP accumulation in response to increasing ANP concentrations in glomeruli (top) and IMCD cells (bottom) obtained from control, low-dose, and high-dose insulin-treated rats. ANP induced a dosedependent increase in cGMP in the three groups. In both glomeruli and IMCD cells, cGMP production was lower in low-dose insulin-treated diabetic rats than in controls at the higher concentrations used. Data are mean \pm SEM of eight control, four low-dose, and five high-dose insulintreated rats for glomeruli and six control, five low-dose, and four highdose insulin-treated rats for IMCD cells.

$(8,32-35)$. This increase in ANP levels could be a consequence of the plasma volume expansion present in both STZ-diabetic rats $(7,31,36,37)$ and patients with diabetes mellitus $(2,38-$ 41). Despite increased plasma levels of ANP, the response to maneuvers known to stimulate the release of the peptide, such as saline infusion, is impaired $(5,31)$. This has been interpreted as a consequence of partial exhaustion of the storage pool of the hormone as also demonstrated by morphologic studies in which the abundance of secretory granules is decreased in atrial cardiomyocytes obtained from diabetic rats $(31,42)$.

Blunted glomerular and tubular responses to volume expansion $(5,6)$ and exogenous ANP infusion (7) have been reported in rats with STZ-induced diabetes. Similarly, a decreased natriuretic response to endogenously secreted ANP has been shown in type 1 diabetic subjects after head-out water immersion (8). In the present study, we found that the number of both biological and clearance ANP receptors is significantly decreased in the kidneys of STZ-diabetic rats, providing an explanation for the decreased renal response to the hormone. Similarly, Benigni et 


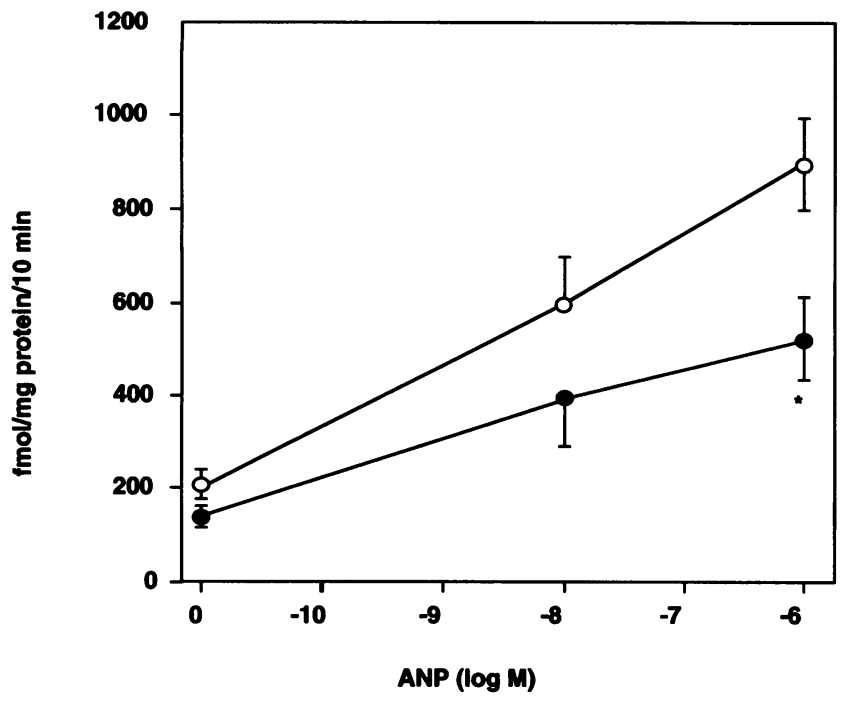

Figure 6. Glomerular cGMP accumulation in control and low-dose insulin-treated rats, in the presence of zaprinast. ANP induced a dosedependent increase in cGMP in both groups. cGMP generation was lower in low-dose insulin-treated diabetic rats at the highest concentration used. Glomerular cGMP generation in high-dose insulin-treated diabetic rats was identical to that shown for control rats. Data are mean \pm SEM of eight control, four low-dose, and five high-dose insulintreated rats.

al. (7) reported a reduction in the number of cortical ANP receptors in rats with STZ-induced diabetes $6 \mathrm{wk}$ after injection. In that study, however, no distinction was made between clearance and biological receptors. Consistent with our findings, no change in receptor affinity was found by those investigators. A reduction in the number of clearance receptors, together with the persistent stimulation of ANP release from atria due to an increase in extracellular fluid volume, could explain the increase in plasma ANP levels found in STZ diabetes.

Most renal actions of ANP are thought to be mediated by cGMP $(43,44)$. Measurement of cGMP in glomeruli incubated in the presence of increasing concentrations of ANP indicated that the glomerular response to the hormone is significantly reduced in STZ-diabetic rats, providing indirect evidence of decreased renal sensitivity to ANP. A decreased response to ANP could be explained by an increased activity of cGMP PDE as described in other proteinuric conditions (45) as well as reduced binding of ANP to the ANPR-A receptor. To evaluate the role of PDE activity in the blunted ANP responsiveness of diabetic glomeruli and IMCD cells, we performed additional experiments in the presence of a PDE inhibitor. Incubation with zaprinast (an inhibitor specific for cGMP PDE) did not correct the difference in ANP-stimulated cGMP generation by glomerular suspensions obtained from hyperglycemic-diabetic and control rats, making unlikely a role of this enzyme in the decreased cGMP accumulation. Similarly, intrinsic activity of membranebound guanylate cyclase did not differ between normals and diabetics, suggesting that alteration in the guanylate cyclase portion of the ANPR-A receptor in its intracellular domain was not altered by the diabetic state, and lending further support to the contention that blunted responsiveness of diabetic kidneys to ANP in vivo (5-7) and impaired cGMP accumulation in vitro (Fig. 5) may be linked to the decrease in binding of ANP which we have demonstrated.
Circulating levels of peptide hormones may directly regulate target tissue receptor number, and plasma concentrations may negatively correlate with the density of specific receptors (46). This also applies to circulating ANP, the levels of which determine receptor density in the kidney (47-49). Therefore, homologous down-regulation caused by increased plasma ANP levels is the most obvious explanation of the decreased ANP receptor number in the kidney of diabetic rats. Alternatively, a decreased number of receptors could reflect a primary phenomenon independent of plasma ANP levels. It has been shown that the number of glomerular receptors for other circulating peptides such as angiotensin II $(50,51)$ and thromboxane $A_{2}(52)$ are decreased in diabetes mellitus. It is also known that glucose levels regulate the activity of protein kinase $C(53,54)$ which in turn regulates the number of receptors present on the cell membrane $(55,56)$. Therefore, it is possible that receptors for different peptides are regulated by plasma glucose levels through changes in the activity of protein kinase C. Further studies will be required to distinguish among these various possibilities.

In summary, our results demonstrate a reduced binding of ANP in both glomeruli and IMCD cells of diabetic rat kidneys. The diminished binding is associated with diminished biological activity in vitro in these target sites of renal ANP action. This abnormality may consequently be the mechanism underlying renal resistance to ANP in diabetic animals and patients.

\section{Acknowledgments}

This research was supported by U. S. Public Health Service research grants HL-11046 and DK-31623 from the National Institutes of Health and grant-in-aid 891124 from the American Heart Association. L. A. Sechi was a recipient of fellowship awards from the Italian Society of Hypertension and the Juvenile Diabetes Foundation International. J.-P. Valentin was a recipient of fellowship awards from International Chemical Industry-Pharma and the American Heart Association, California Affiliate.

\section{References}

1. O'Hare, J. A., J. B. Ferriss, D. Brady, B. Twomey, and D. J. O'Sullivan. 1985. Exchangeable sodium and renin in hypertensive diabetic patients with and without nephropathy. Hypertension (Dallas). 7(Suppl. 2):43-48.

2. Feldt-Rasmussen, B., E. R. Mathiesen, T. Dekert, J. Giese, N. J. Christensen, L. Bent-Hansen, and M. D. Nielsen. 1987. Central role for sodium in the pathogenesis of blood pressure changes independent of angiotensin, aldosterone and catecholamines in type 1 (insulin-dependent) diabetes mellitus. Diabetologia. 30:610617 .

3. Ilstrup, K. M., W. F. Keane, and L. D. Michels. 1981. Intravascular and extravascular volumes in the diabetic rat. Life Sci. 29:717-724.

4. Guyton, A. C. 1992. Kidneys and fluids in pressure regulation; small volume but large pressure changes. Hypertension (Dallas). 19(Suppl. I):2-8.

5. Patel, K. P., and P. L. Zhang. 1989. Reduced renal responses to volume expansion in streptozotocin-induced diabetic rats. Am. J. Physiol. 257:R672R679.

6. Patel, K. P., and P. L. Zhang. 1990. Attenuated renal responses to atrial natriuretic factor in streptozotocin-induced diabetic rats. Can. J. Physiol. Pharma col. $68: 425-430$.

7. Benigni, A., N. Perico, J. Dadan, M. Gabanelli, M. Galbusera, P. Boccardo, T. Mennini, and G. Remuzzi. 1990. Functional implications of decreased cortical atrial natriuretic peptide binding in experimental diabetes. Circ. Res. 66:14531460.

8. Lieberman, J. S., L. Parra, L. Newton, J. D. Scandling, N. Loon, and B. D. Myers. 1991. Atrial natriuretic peptide and response to changing plasma volume in diabetic nephropathy. Diabetes. 40:893-901.

9. Koller, K. J., D. G. Lowe, G. L. Bennett, N. Minamino, K. Kingawa, H. Matsuo, and D. V. Goeddel. 1991. Selective activation of the B natriuretic peptide receptor by C-type natriuretic peptide. Science (Wash. DC). 252:120-123.

10. Chang, M. S., D. G. Lowe, M. Lewis, R. Hellmiss, E. Chen, and D. V. 
Goedel. 1989. Differential activation by atrial and brain natriuretic peptides of two different receptor guanylate cyclases. Nature (Lond.). 341:68-72.

11. Anand-Srivastava, M. B., M. R. Sairam, and M. Cantin. 1990. Ringdeleted analogs of atrial natriuretic factor inhibit adenylate cyclase/cAMP system. J. Biol. Chem. 265:8566-8572.

12. Lewicki, J. A., D. B. Schenk, F. Fuller, G. Porter, G. A. McEnroe, A. Arfsten, K. Schwartz, L. L. Kang, T. Maack, and R. M. Scarborough. 1988. Pharmacological and biochemical studies of atrial natriuretic peptide receptor subpopulations. In Advances in Atrial Peptide Research. 2nd ed. B. M. Brenner and J. H. Laragh, editors. Raven Press, New York. 31-39.

13. Scarborough, R. M., D. B. Schenk, G. A. McEnroe, A. Arfsten, L. L. Kang, K. Schwartz, and J. A. Lewicki. 1986. Truncated atrial natriuretic peptide analogs. J. Biol. Chem. 261:12960-12964.

14. Song, D. L., K. P. Kohse, and F. Murad. 1988. Brain natriuretic factor Augmentation of cellular cyclic cGMP, activation of particulate guanylate cyclase and receptor binding. FEBS (Fed. Eur. Biochem. Soc.) Lett. 232:125-129.

15. Takayangi, R., T. Inagami, R. M. Snajdar, T. Imada, M. Tamura, and K. S. Misono. 1987. Two distinct forms of receptors for atrial natriuretic factor in bovine adrenocortical cells. J. Biol. Chem. 262:12104-12113.

16. Almeida, F. A., M. Suzuki, R. M. Scarborough, J. A. Lewicki, and T. Maack. 1989. Clearance functions of type $C$ receptors of atrial natriuretic factor in rats. Am. J. Physiol. 256:R469-R475.

17. Fuller, F., J. G. Porter, A. E. Arfsten, J. Miller, J. W. Schilling, R. M. Scarborough, J. A. Lewicki, and D. B. Schenk. 1988. Atrial natriuretic peptide clearance receptors. J. Biol. Chem. 263:9395-9401.

18. Maack, T., M. Suzuki, F. A. Almeida, D. Nussenzveig, R. M. Scarborough, G. A. McEnroe, and J. A. Lewicki. 1987. Physiological role of silent receptors of atrial natriuretic factor. Science (Wash. DC). 238:675-678.

19. Brown, J., S. P. Salas, A. Singleton, J. M. Polak, and C. T. Dollery. 1990. Autoradiographic localization of atrial natriuretic peptide receptor subtypes in rat kidney. Am. J. Physiol. 259:F26-F39.

20. Valentin, J.-P., L. A. Sechi, C. Qiu, M. Schambelan, and M. H. Humphreys 1993. Urodilatin binds to and activates renal receptors for atrial natriuretic peptide. Hypertension (Dallas). 21:432-438.

21. Wilcox, J. N., A. Augustine, D. V. Goeddel, and D. G. Lowe. 1991. Differential regional expression of three natriuretic peptide receptor genes within primate tissues. Mol. Cell. Biol. 11:3454-3462.

22. Munson, P. J., and D. Rodbard. 1980. Ligand: a versatile computerized approach for characterization of ligand binding systems. Anal. Biochem. 107:220239.

23. Schambelan, M., S. Blake, J. Sraer, M. P. Bens, M. P. Nivez, and F. Wahbe. 1985. Increased prostaglandin production by glomeruli isolated from rats with streptozotocin-induced diabetes mellitus. J. Clin. Invest. 75:404-412.

24. Zeidl, M. L., P. Silva, B. M. Brenner, and G. L. Seifter. 1987. cGMP mediates effects of atrial peptides on medullary collecting duct cells. Am. J. Physiol. 252:F551-F559.

25. Lowry, O. H., N. J. Rosebrough, A. L. Farr, and L. J. Randall, 1951. Protein measurement with the Folin phenol reagent. J. Biol. Chem. 193:265-275.

26. Cunning, M., P. Silva, B. M. Brenner, and M. L. Zeidel. 1989. Characteristics of ANP-sensitive guanylate cyclase in inner medullary collecting duct cells. Am. J. Physiol. 256:F766-F775.

27. Torres, V. E., V. S. F. Hui, S. V. Shah, T. E. Northrup, and T. P. Dousa 1978. Cyclic nucleotide phosphodiesterase in glomeruli of rat renal cortex. Kidney Int. 14:444-451.

28. Wells, J. N., C. E. Baird, Y. J. Wu, and J. G. Hardman. 1975. Cyclic nucleotide phosphodiesterase activities of pig coronary arteries. Biochim. Biophys. Acta. 384:430-442.

29. Chai, S. Y., P. M. Sexton, A. M. Allen, R. Figdor, and F. A. O. Mendelsohn. 1986. In vitro autoradiographic localization of ANP receptors in rat kidney and adrenal gland. Am. J. Physiol. 250:F753-F757.

30. Sahai, A., and P. K. Ganguly. 1991. Congestive heart failure in diabetes with hypertension may be due to uncoupling of the atrial natriuretic peptide receptor-effector system in the kidney basolateral membrane. Am. Heart J. 122:164-170.

31. Hebden, R. A., M. E. Todd, and J. H. McNeill. 1989. Relationship between atrial granularity and release of atrial natriuretic factor in rats with diabetes mellitus. Am. J. Physiol. 257:R932-R938.

32. Shinoda, T., M. Ishihara, F. Kurimoto, T. Aizawa, K. Hiramatsu, T. Shirota, N. Takasu, and T. Yamada. 1990. Elevated plasma atrial natriuretic peptide level in the early phase of microalbuminuria in patients with non-insulindependent diabetes mellitus. Clin. Nephrol. 34:202-207.

33. Sawicki, P. T., L. Heinemann, K. Rave, A. Hohman, and M. Berger. 1988. Atrial natriuretic factor in various states of diabetic nephropathy. J. Diabetic Complications. 2:207-209.
34. Suzuki, Y., H. Suzuki, R. Ohtake, T. Tsuchiya, H. Muramatsu, Y. Hashigami, H. Kobori, and S. Shimoda. 1988. Plasma and urine concentrations of atrial natriuretic peptide in patients with diabetes mellitus. Pancreas. 3:404-408.

35. Bell, G., K. Berstein, J. H. Laragh, S. A. Atlas, G. D. James, M. S. Peker, and J. E. Sealey. 1989. Increased plasma atrial natriuretic factor and reduced plasma renin in patients with poorly controlled diabetes mellitus. Clin. Sci. 77:177-182.

36. Hostetter, T. H., J. L. Troy, and B. M. Brenner. 1981. Glomerular hemodynamics in experimental diabetes mellitus. Kidney Int. 19:410-415.

37. Allen, T. J., M. E. Cooper, R. C. O'Brien, L. A. Bach, B. Jackson, and G. Jerums. 1990. Glomerular filtration rate in streptozotocin-induced diabetic rats. Role of exchangeable sodium, vasoactive hormones, and insulin therapy. Diabetes. 39:1182-1190.

38. Brochner-Mortensen, J. 1973. Glomerular filtration rate and extracellular volumes during normoglycemia and moderate hyperglycemia in diabetes. Scand. J. Clin. Lab. Invest. 32:311-316.

39. Christlieb, A. R. 1974. Renin, angiotensin, and norepinephrine in alloxan diabetes. Diabetes. 23:962-970.

40. Weidman, P. C., G. Beretta-Piccoli, G. Keusch, Z. Glueck, M. Mujagic, A. Meier, and W. H. Ziegler. 1979. Sodium-volume factor, cardiovascular reactivity and hypotensive mechanisms of diuretic therapy in hypertension associated with diabetes mellitus. Am. J. Med. 67:779-784.

41. Ferriss, J. A., J. A. O'Hare, M. Cole, B. Twomey, and J. D. O'Sullivan 1986. Blood pressure in diabetic patients: relationships with exchangeable sodium and renin activity. Diabetic Nephrol. 5:27-30.

42. Chua, B. H. L., C. C. Chua, and S. L. Rose. 1988. Atrial natriuretic factor production in diabetes and hypertrophied hearts. Am. Soc. Hypertens. Symp. Ser. 2:312-315.

43. Hamet, P., J. Tremblay, S. Pang, R. Skuherska, E. L. Schiffrin, R. Garcia M. Cantin, J. Genest, R. Palmour, F. R. Ervin, S. Martin, and R. Goldwater. 1985. Cyclic GMP as mediator and biological marker of atrial natriuretic factor. $J$. Hypertens. (Suppl. 2):S49-S56.

44. Wong, K. R., M. H. Xie, L. B. Shi, F. Y. Liu, C. L. Huang, D. G. Gardner, and M. G. Cogan. 1988. Urinary cGMP as biological marker of the renal activity of atrial natriuretic factor. Am. J. Physiol. 255:F1220-F1224.

45. Valentin, J.-P., C. Qiu, W. P. Muldowney, W. Z. Ying, D. G. Gardner, and M. H. Humphreys. 1992. Cellular basis for blunted volume expansion natriuresis in experimental nephrotic syndrome. J. Clin. Invest. 90:1302-1312.

46. Catt, K. J., J. P. Harwood, G. Aguilera, and M. L. Dufau. 1979. Hormonal regulation of peptide receptors and target cell responses. Nature (Lond.) 280:109116

47. Tsunoda, K., F. A. O. Mendelsohn, P. M. Sexton, S. Y. Chai, G. P. Hodsman, and C. I. Johnston. 1988. Decreased atrial natriuretic peptide binding in renal medulla in rats with chronic renal failure. Circ. Res. 62:155-161.

48. Ballerman, B. J., K. D. Block, J. G. Seidman, and B. M. Brenner. 1986. Atrial natriuretic peptide transcription, secretion, and glomerular receptor activity during mineralocorticoid escape in the rat. J. Clin. Invest. 78:840-843.

49. Gaquelin, G., E. L. Schiffrin, M. Cantin, and R. Garcia. 1987. Specific binding of atrial natriuretic factor to renal glomeruli in doca- and doca-salt-treated rats, correlations with atrial and plasma levels. Biochem. Biophys. Res. Commun. 145:522-531

50. Wilkes, B. M. 1987. Reduced glomerular angiotensin II receptor density in diabetes mellitus in the rat: time course and mechanism. Endocrinology. 210:1291-1298.

51. Ballerman, B. J., K. L. Skoreki, and B. M. Brenner. 1984. Reduced glomerular angiotensin II receptor density in early untreated diabetes mellitus in the rat. Am. J. Physiol. 247:F110-F116.

52. Wilkes, B. M., R. Kaplan, P. F. Mento, H. S. Aynedjian, C. M. Macica D. Schlondorff, and N. Bank. 1992. Reduced glomerular thromboxane receptor sites and vasoconstrictor responses in diabetic rats. Kidney Int. 41:992-999.

53. Craven, P. A., and F. R. DeRubertis. 1989. Protein kinase C is activated in glomeruli from streptozotocin diabetic rats. Possible mediation by glucose. $J$. Clin. Invest. 83:1667-1675.

54. Lee, T.-S., K. A. Saltsman, H. Ohashi, and G. L. King. 1989. Activation of protein kinase $\mathrm{C}$ by elevation of glucose concentration: proposal for a mechanism in the development of diabetic vascular complications. Proc. Natl. Acad. Sci. USA. 86:5141-5145.

55. Roubert, P., V. Gillard, P. Plas, J.-M. Guillon, P.-E. Chabrier, and P. Braquet. 1989. Angiotensin II and phorbol-esters potently down-regulate endothelin (ET-1) binding sites in vascular smooth muscle cells. Biochem. Biophys. Res. Commun. 164:809-815.

56. Williams, B., P. Tsai, and R. W. Schrier. 1991. Angiotensin II (Ang II) and arginine vasopressin (AVP) receptor desensitization in rat vascular smooth muscle cells due to glucose activated protein kinase C (PKC). J. Am. Soc. Nephrol. 1:483a. (Abstr.) 